\title{
Effects of Rubus coreanus and Artemisia princeps Extracts on the Ultraviolet B-Induced DNA Damage Responses in HaCaT Cells
}

\author{
Seok Hee Lee ${ }^{1}$, Se Eun $\mathrm{Ha}^{1}$, Jun Kyoung $\mathrm{Lee}^{2}$ and Jong Kun Park ${ }^{1 *}$ \\ ${ }^{1}$ Research Institute for Basic Science and Division of Biological Science, Wonkwang University, Iksan, Jeonbuk, 570-749, Korea \\ ${ }^{2}$ Hanpoong Pharm Co. LTD., Jeonju, Jeonbuk, 561-841, Korea
}

Received November 19, 2013 /Revised January 3, 2014 / Accepted February 10, 2014

\begin{abstract}
We investigated the effects of extracts from Rubus coreanus (RC) and Artemisia princeps var. orientalis (AP) on DNA damage response in ultraviolet B (UVB)-exposed HaCaT cells. Cell activity upon treatment for $24 \mathrm{~h}$ with $\mathrm{RC}$ or AP alone was similar to or greater than that of the nontreated control. When UVB-exposed cells were postincubated for $24 \mathrm{~h}$ in medium containing RC or AP, cell activity increased in a concentration-dependent manner. Nuclear fragmentation analysis showed that postincubation with RC or AP decreased UVB-induced apoptosis by about $20 \%$ and $15 \%$, respectively, of that in cells postincubated with growth medium. When UVB-exposed cells were postincubated for 24 $h$ in medium containing RC or AP, the level of cyclobutane pyrimidine dimer decreased in a concentration-dependent manner. Western blot analysis showed that treatment of cells not exposed to UVB with RC or AP alone did not significantly change the levels of phospho-p53 and GADD45 protein. Interestingly, when UVB-exposed cells were postincubated for $24 \mathrm{~h}$ in medium containing $\mathrm{RC}$ or $\mathrm{AP}$, phospho-p53 and GADD45 levels decreased in a concentration dependent manner. Our results suggest that RC and AP extract assist the survival of UVB-exposed cells in parallel with a decrease in levels of UVB-induced DNA damage and damage-response proteins, such as p53 and GADD45.
\end{abstract}

Key words : Artemisia princeps var. orientalis, GADD45, p53, Rubus coreanus, UVB

\section{서 론}

자외선은 인간 피부 세포에 있어서 해로운 점과 유익한 점 두 가지 측면을 지니고 있다. 유익한 측면은 피부 진피에서 비타민 $\mathrm{D}$ 의 생성을 중재하는 역할을 하는 것이고 해로운 측면 은 눈에 만성적인 해를 입히거나 화상, 염증반응, 세포사멸, 피부암을 일으킬 수 있다[32]. 자외선 B는 290-320 nm 파장대 로 피부에 과도하게 조사되면 DNA 상해를 형성하게 만들어 세포고사 과정을 유도한다. 자외선에 의해 유도된 DNA 상해 는 cyclobutane pyrimidine dimers $(\mathrm{CPD})$ 와 같은 특이적인 DNA 상해를 포함하여, 상해부위를 포함하고 있는 뉴클레오 티드는 절제효소 복합체에 의해 제거되기도 하지만, 과도한 수준의 DNA 상해는 절제회복을 거치지 않고 세포고사로 이 어진다[27, 31]. 상해를 입은 피부세포에서는 활성산소가 과다 생성되어 단백질, 지질 그리고 $\mathrm{DNA}$ 의 산화 과정이 유도되며, 독성 산물을 생산하고 산화적인 상해가 가속화되어 세포고사 과정이 유도된다[30]. 뿐만 아니라 자외선은 색소침착, 광노화,

\section{*Corresponding author}

Tel : +82-63-850-6200, Fax : +82-63-843-2781

E-mail : jkpark@wku.ac.kr

This is an Open-Access article distributed under the terms of the Creative Commons Attribution Non-Commercial License (http://creativecommons.org/licenses/by-nc/3.0) which permits unrestricted non-commercial use, distribution, and reproduction in any medium, provided the original work is properly cited
화상, 홍반, 암 등 인간 피부 세포에 나타나는 다양한 현상의 원인이 되기도 한다[27]

자외선 $\mathrm{B}$ 를 과도하게 조사하면 $\mathrm{DNA}$ 상해 반응이 일어나 $\mathrm{ATM}$ 의 활성화가 일어나고, 하위 유전자인 $\mathrm{p} 53$ 을 활성화시켜 $\mathrm{DNA}$ 회복과 세포고사, 세포 주기의 정지를 개시한다고 보고 되고 있다[3, 25]. 자외선 $\mathrm{B}$ 에 의해 유도된 DNA 상해 반응에서 p53 유전자가 DNA 회복과 세포 주기 중 G1기에서 정지를 유도하여 증식을 억제하는 중요한 기능을 한다. 인산화된 p53 단백질 등에 의해서 전사가 활성화되는 GADD45 유전자는 세포의 다양한 스트레스 반응에 연관된 유전자로 $\mathrm{G}_{2} / \mathrm{M}$ 기의 진행을 방해하거나 DNA의 탈 메틸화, DNA 상해 회복을 조 절하여 유전체 안정화를 시키는 역할을 하며, 세포고사에도 관여한다 $[9,29]$.

복분자(Rubus coreanus)는 한국, 중국, 일본이 속해 있는 북 아시아 지역에 한정되어 있으며, 장미과에 속하는 넓은 잎의 낙엽관목이다. 복분자의 성분으로는 tannin, gallotannin, gallic acid, ferulic acid, epicatechin, ellagic acid, antocyanin과 같은 다양한 항산화 성분이 풍부하게 포함되어 있다 $[2,5]$. Choung과 Lim [8]은 hydroxy radical은 약 $60 \%$, superoxide anion radical은 catechin 보다 약 $80 \%$ 소거 활성 증가의 결과 를 토대로 복분자 안토시아닌 성분의 항산화 효과에 대해 보 고하였다. 복분자는 또한 전립선과 간 질환, 알레르기성 질환, 천식 등의 치료제로 사용되고 있으며, 뼈세포의 증식 및 분화 를 촉진하고 결장암 및 전립선 암의 발생을 억제하는 것으로 
보여지며, 항염증 효과를 나타내는 것으로 보고되고 있다[2, 14, 18].

쑥(Artemisia princeps var. orientalis, $)$ 은 국화과에 속해 있는 다년생 식물로서 중국, 일본, 한국 등 아시아에 넓게 분포 되어 있다. 쑥은 과민증이나 당뇨병에 대한 완화효과와, 항균 및 항알레르기 효과가 있어 음식과 치료제로 다양하게 사용되고 있다[26, 34]. Jung 등[17]은 쑥이 항산화 효과가 뛰어난 상황버 섯 보다 1,1-diphenyl-2-picrylhydrazyl (DPPH) free radical에 대해 약 $60 \%$ 정도 소거 활성을 보였고, hydroxy radical의 수 준을 $100 \mu \mathrm{g} / \mathrm{ml}$ 에서 약 $10 \%$ 로 감소시켰으며, 인간의 위암세 포와 결장암 세포에서 각각 약 $70 \%, 50 \%$ 정도 암세포 성장이 억제됨을 보고하였다.

그러나 복분자 및 쑥 추출물에서 DNA 상해 반응에 대한 보고는 거의 없어서 본 연구에서는 $\mathrm{HaCaT}$ 세포안에서 자외선 $\mathrm{B}$ 에 의해 유도된 DNA 상해반응 즉, 세포고사, DNA 상해 수 준, 그리고 p53 의존성 단백질 수준에 대해 복분자, 쑥 추출물 이 미치는 영향을 규명하고자 하였다.

\section{재료 및 방법}

\section{추출물}

복분자(Rubus coreanus, $\mathrm{RC})$ 와 쑥(Artemisia princeps var. orientalis, AP)은 원광허브에서 구입하여 사용하였다. 원료는 시 험 성적서를 통해 기원을 확인하였으며 잔류농약, 잔류이산화 황, 중금속 시험 등의 유해물질 검사에서 모두 적격품임을 확 인 후 제조에 사용하였다. 총 $1 \mathrm{~kg}$ 에 $30 \%$ 에탄올을 10 배수로 첨가하여 $95 \sim 100^{\circ} \mathrm{C} 3$ 시간 동안 2 회 환류 추출 한 후, 추출액 을 $25 \mu \mathrm{m}$ 거름종이로 여과하여 감압농축 하였다. 건조는 60 $70^{\circ} \mathrm{C}$ 감압열풍으로 건조하여 실험에 사용하였다.

\section{세포배양 및 자외선 조사}

인간 각질 세포주인 $\mathrm{HaCaT}$ 세포는 $10 \%$ fetal bovine serum (FBS)와 $2 \mathrm{mM}$ L-glutamine이 함유되어 있는 RPMI-1640 (Gibco)에서 $37^{\circ} \mathrm{C}, 5 \% \mathrm{CO}_{2}$ 배양기(Sanyo)에서 24시간 배양하 였다. $\mathrm{HaCaT}$ 세포를 PBS로 세척한 후 UVB (280-320 mm) 200 $\mathrm{J} / \mathrm{m}^{2}$ 를 조사하고 정상배지 또는 $\mathrm{RC}$ 와 $\mathrm{AP}$ 추출물을 각각 농도 별로 함유된 배지를 처리하여 적정시간 동안 배양하였다.

\section{세포 활성도 분석}

세포 활성도 실험은 3-[4,5-dimethylthiazol-2-yl]-2,5-diphenyl tetrazolium bromide (MTT) (Sigma)를 이용하여 측정 하였다. $\mathrm{HaCaT}$ 세포는 96 well multiplate (Nunc)에 각 well 당 $1 \times 10^{5}$ 개의 세포를 분주하고, 24 시간 동안 배양한 후 FBS가 첨가된 새 배지로 교환하고 실험에 사용될 $\mathrm{RC}$ 와 $\mathrm{AP}$ 추출물을 다양한 농도에서 24시간 처리하였다. 배양 후 phosphate buffered saline (PBS)로 세척한 후 $0.5 \mathrm{mg} / \mathrm{ml}$ 의 MTT 용액 100 $\mathrm{ml}$ 을 넣고, 4 시간 동안 $37^{\circ} \mathrm{C}$ 에서 배양한 후, $570 \mathrm{~nm}$ 에서 흡광 도(ELISA reader, ReTiSoft)로 측정하여 그 효과를 정상 대조 군에 대한 백분율로 산출하여 비교하였다.

\section{세포 고사에 의한 핵분절 분석}

자외선을 조사한 후 $\mathrm{RC}$ 와 $\mathrm{AP}$ 추출물을 각각 처리하여 핵의 형태 변화를 관찰하고자 DAPI 염색을 수행하였다. $200 \mathrm{~J} / \mathrm{m}^{2}$ $\mathrm{UVB}$ 를 조사하고 추출물을 각각의 농도 별로 처리하여 24 시간 동안 배양한 후 DAPI 염색하여 형광현미경(Zeiss)으로 관찰하 였다. 결과는 핵이 분절된 세포의 전체 세포에 대한 백분율로 계산하여 비교하였다.

\section{DNA 상해 수준 분석}

티민(Thymine)이 연속된 DNA 서열에 자외선이 가해지면 cyclobutane pyrimidine dimer $(\mathrm{CPD})$ 를 형성하게 된다. DNA 상해 수준 분석은 genomic DNA를 추출하고 slot blot을 이용 하여 여과막에 부착한 후 anti-CPD 항체와 반응시킨 이미지의 광학 밀도를 분석하고 자외선 조사 직후의 $\mathrm{CPD}$ 양에 대한 상대 값을 결정하였다.

\section{Western blot}

Lowery 방법에 따라 세포를 용해한 후 얼음에서 20분간 처리하고 원심분리 $\left(12,000 \mathrm{rpm}, 5\right.$ 분, $\left.4^{\circ} \mathrm{C}\right)$ 하여 단백질이 함유 된 상층액만을 회수하였다. 정량한 단백질은 $12 \%$ SDSpoly-acrylamide gel에서 분리시킨 후 Eletroblot system (Bio $\mathrm{Rad})$ 을 사용하여 $250 \mathrm{~mA}$ 로 1시간 동안 polyvinylidene fluoride 막에 옮겼다. TBS-T 완충용액으로 세척하고 5\% skim milk에 놓아두었다. 각각의 항체가 들어있는 항혈청을 blocking 용액에 1:1,000으로 희석한 용액을 처리한 후 TBS-T로 세 척하였다. 암실에서 developing solution $\mathrm{A}$ 와 $\mathrm{B}$ 를 1:1로 혼합 한 액을 처리한 후 곧 바로 Hyper film을 얹어 10 초에서 5 분 동안 노출한 후 현상하였다.

\section{결과 및 고찰}

세포 활성도는 3-[4,5-dimethylthiazol-2-yl]-2,5-diphenyl tetrazolium bromide (MTT) 방법으로 분석하였다. 복분자 (Rubus coreanus, RC)와 쑥(Artemisia princeps var. orientalis, $\mathrm{AP})$ 추출물을 처리했을 때 시료를 처리하지 않은 대조군에 비해 $600 \mu \mathrm{g} / \mathrm{ml}$ 농도까지 유의적인 차이를 나타내지 않았으 며, $800 \mu \mathrm{g} / \mathrm{ml}$ 이상의 농도에서 세포독성을 나타내었다(Fig. 1). 배양세포에 자외선 $\left(200 \mathrm{~J} / \mathrm{m}^{2}\right)$ 을 조사한 후 24 시간 동안 다 양한 농도의 $\mathrm{RC}$ 와 $\mathrm{AP}$ 추출물을 처리하여 세포 유전독성에 대한 추출물의 효과를 분석하였다. 자외선 조사에 의해 정상 대조군보다 약 $50 \%$ 감소된 세포 활성도는 $\mathrm{RC}$ 와 $\mathrm{AP}$ 추출물 처리에 의해 처리하지 않은 대조군에 비교하여 상대적인 고농 


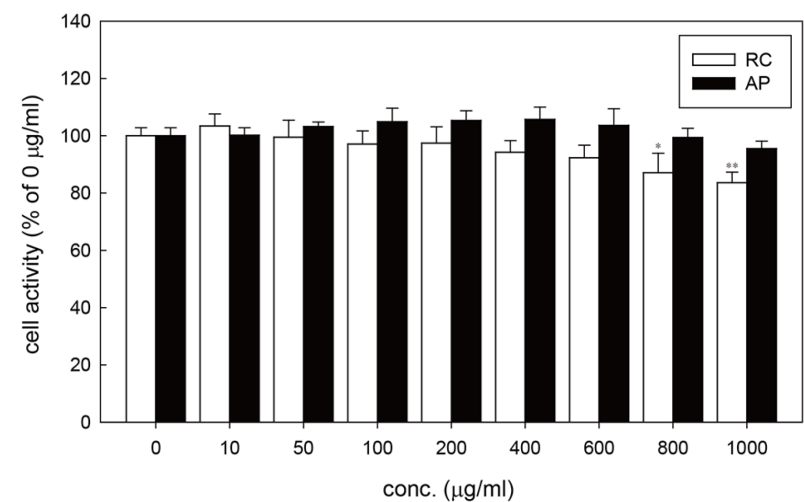

Fig. 1. Activity of cells treated with various concentrations of extracts from Rubus coreanus (RC) (white bars) and Artemisia princeps var. orientalis (AP) (black bars) as determined by MTT assay. ${ }^{*}$, Data represent the mean \pm $\mathrm{SD}$ of at least triplicate experiments. ${ }^{*}, p<0.05$ and ${ }^{* *}$, $p<0.01$, respectively, versus groups postincubated with growth medium $(0 \mu \mathrm{g} / \mathrm{ml})$.

\section{도에서 각각 약 $14 \%, 20 \%$ 로 증가하였다(Fig. $2 \mathrm{~A}$ ).}

자외선에 의한 세포고사에서 대한 효과를 알아보기 위해서 세포고사 때 나타나는 핵 분절화 현상을 DAPI 염색을 통해 분석하고 그 결과를 세포 고사율로 제시하였다(Fig. 2B). 200 $\mathrm{J} / \mathrm{m}^{2}$ 자외선을 조사한 후 $\mathrm{RC}$ 와 $\mathrm{AP}$ 추출물을 농도별로 처리한 결과 농도 의존적으로 감소하여 고농도에서는 각각 약 20 , $15 \%$ 정도의 세포 고사가 저해되는 것을 확인하였다(Fig. 2B). 이 결과는 세포 활성도의 결과(Fig. 1, Fig. 2A)와 거의 일치하 는 것으로 보아 $\mathrm{RC}$ 와 $\mathrm{AP}$ 추출물이 자외선에 의한 세포고사를 저해하고, 세포를 상해원으로부터 보호하는 효과를 지니는 것 으로 생각된다.

$\mathrm{DNA}$ 상해 반응 회복에 미치는 영향을 확인하기 위해서 $\mathrm{CPD}$ 잔여량을 측정하여 분석하였다. 그 결과, $\mathrm{RC}$ 와 $\mathrm{AP}$ 추출 물만 각각 처리했을 때 처리하지 않은 대조군에 비해 유의적 인 차이를 나타내지 않았으나(Fig. $3 \mathrm{~A}$ ), 자외선을 조사한 후

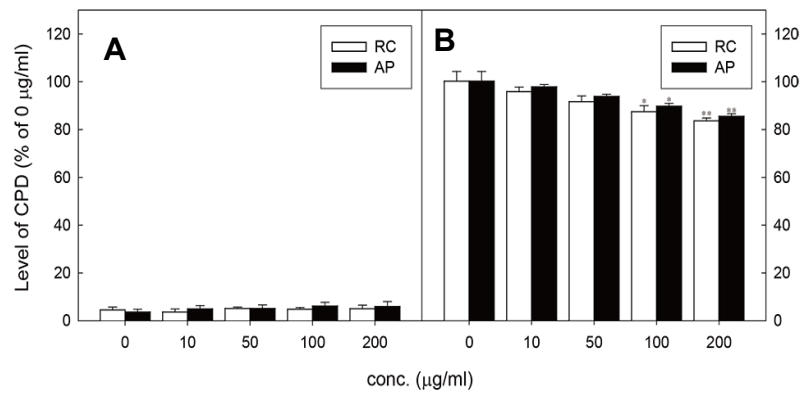

Fig. 3. Relative levels of $\mathrm{CPD}$ in cells nonirradiated (A) or exposed to UVB $\left(200 \mathrm{~J} / \mathrm{m}^{2}\right)$ (B) and postincubated with various concentrations of $\mathrm{RC}$ (white bars) and $\mathrm{AP}$ (black bars) extracts. *, Data represent the mean \pm SD of at least triplicate experiments. *, $p<0.05$ and ${ }^{* *}, p<0.01$, respectively, versus groups postincubated with growth medium $(0 \mu \mathrm{g} / \mathrm{ml})$.

$\mathrm{RC}$ 와 $\mathrm{AP}$ 추출물을 각각 처리한 경우 정상배지 처리군에 비해 농도 의존적으로 $\mathrm{CPD}$ 양이 점차 감소하였다. 특히, 상대적인 고농도에서 $\mathrm{RC}$ 추출물은 약 $17 \%$ 정도 감소하고 $\mathrm{AP}$ 추출물은 약 $15 \%$ 정도 감소하였다(Fig. $3 \mathrm{~B}$ ). 자외선에 의한 세포활성 억제와 세포고사로부터 보호하는 효과뿐만 아니라 DNA 상해 반응 회복의 효과까지 나타는 것으로 시사된다.

세포 상해에 미치는 영향을 분자적으로 확인하기 위해 phospho-p53, GADD45의 단백질 수준을 Western blot으로 분석하였다(Fig. 4). RC와 $\mathrm{AP}$ 추출물만 각각 처리했을 때 처리 하지 않은 대조군에 비해 큰 차이를 나타내지 않았다(data not shown). 그러나 자외선을 조사한 후 $\mathrm{RC}$ 와 $\mathrm{AP}$ 추출물을 각각 처리한 경우 정상배지 처리군에 비해 농도 의존적으로 phospho-p53, GADD45 단백질 발현량이 감소하였다. 특히, 상대적 인 고농도에서 phospho-p53, GADD45 단백질 발현량을 RC 추출물은 각각 약 $53 \%, 57 \%$ 정도 감소시키며(Fig. $4 \mathrm{~A}), \mathrm{AP}$ 추출물은 각각 약 $43 \%, 57 \%$ 정도 감소시키는 것으로 나타났다 (Fig. 4B).
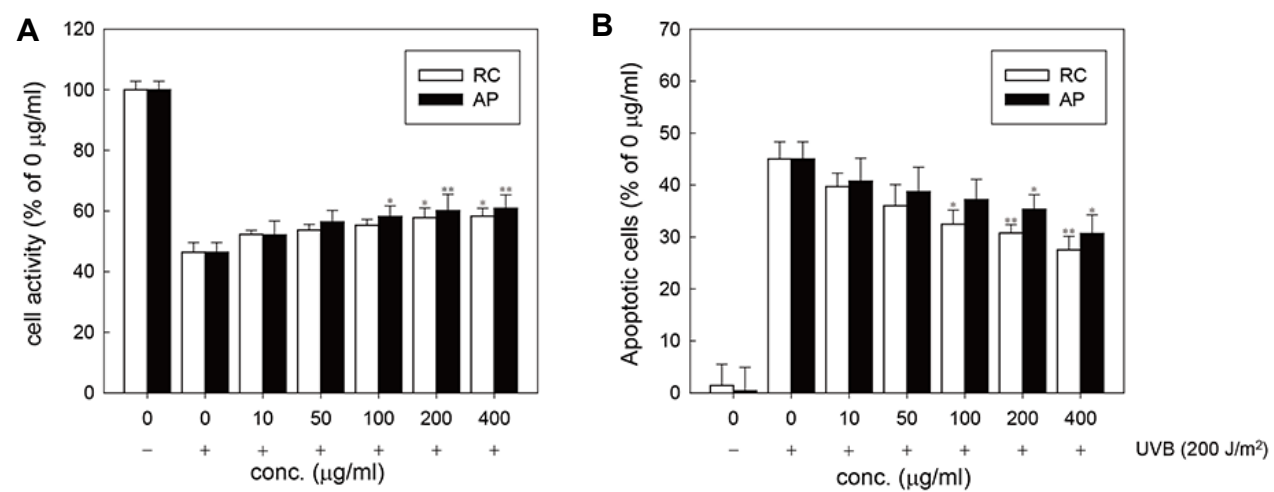

Fig. 2. Activity (A) or apoptotic index (B) of cells exposed to UVB $\left(200 \mathrm{~J} / \mathrm{m}^{2}\right)$ and postincubated with various concentrations of $\mathrm{RC}$ (white bars) and AP (black bars) extracts. *, Data represent the mean $\pm \mathrm{SD}$ of at least triplicate experiments. *, $p<0.05$ and $* *, p<0.01$, respectively, versus groups postincubated with growth medium $(0 \mu \mathrm{g} / \mathrm{ml})$. 

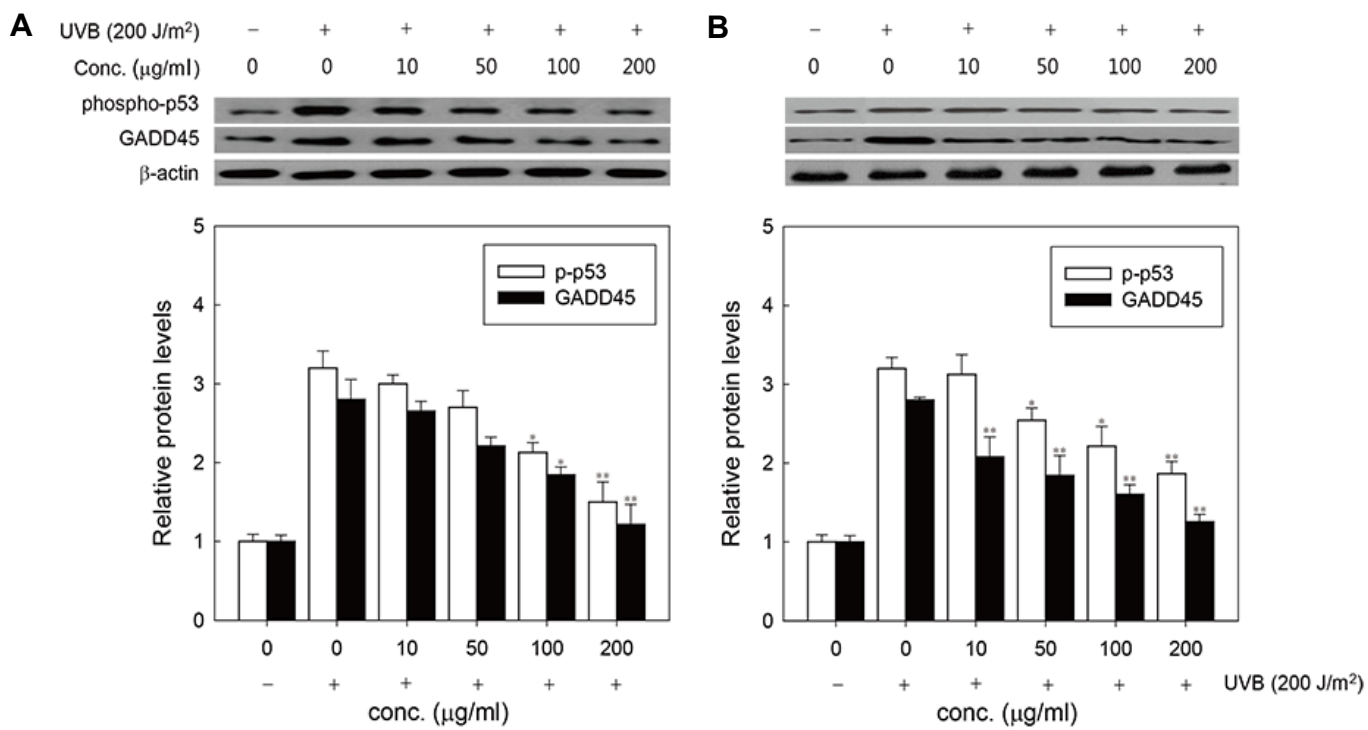

Fig. 4. Effects of postincubation for $24 \mathrm{~h}$ with various concentrations of RC (A) and AP (B) on the levels of phospho-p53 (white bars) and GADD45 (black bars) proteins in $200 \mathrm{~J} / \mathrm{m}^{2}$ UVB-exposed HaCaT cells. Representative western blot products (upper) of p-p53 and GADD45 protein levels as compared with beta actin protein levels as determined by densitometric measurements of the band and normalized (lower) to those in non-treated control. Data represent the mean \pm SD of at least triplicate experiments. ${ }^{*}, p<0.05$ and ${ }^{* *}, p<0.01$, respectively, versus groups postincubated with growth medium $(0 \mu \mathrm{g} / \mathrm{ml})$.

p53 단백질은 상해 받은 DNA를 복구하거나, DNA 상해가 많을 경우 세포를 고사 시켜는 단백질로 알려져 있다. UVB나 활성산소 등 DNA 상해 요인들에 의해 DNA가 상해 받았을 경우에 p53 단백질은 ATM 등의 상위 유전자 산물에 의해 인 산화되어 활성화 되고 $\mathrm{p} 53$ 의존성 신호 전달 및 전사활성화를 통해 p53 의존성 단백질인 p21, GADD45 등의 수준을 향상시 키는 조절작용을 수행한다. 따라서, $\mathrm{p} 53$ 의 역할은 세포고사뿐 만 아니라 GADD45를 통해 DNA 회복과 연관 됨이 보고되었 다 $[3,9,10]$.

$\mathrm{RC}$ 물 추출물은 항산화 효과[16]를 나타내며, RC 에탄올 추출물은 UVB 에 의해 상해 받은 인간 피부 섬유아 세포에서 collagen 단백질의 증가와 MMP 단백질의 감소에 의해 피부 노화에 대한 방어 효과를 나타냄이 보고되었다[1]. 또한, RC 에탄올 추출물은 전립선 암 세포에서 세포 고사에 관여하는 유전자인 BCl-2, Bax를 조절하여 암세포 증식 억제효과 및 항 암 효과가 있음이 보고되었다[22]. AP 에탄올 및 메탄올 추출 물은 DPPH 감소 및 catalase, SOD 활성을 증가시켜 항산화 효과를 나타내고[6, 21], 메탄올 추출물의 경우 간암세포에서 세포 손상 및 고사에 관여하는 유전자인 $\mathrm{p} 53, \mathrm{BCl}-2$ 그리고 $\mathrm{Bax}$ 를 조절하여 세포 성장 및 주기를 저해시켜 항암효과[6]를 보이며, 이 외에도 항염효과[4], 지방생성 유전자산물의 감소 를 통한 억제효과[21]가 보고되었다.

본 연구에서는 자외선 스트레스에 의해 발현된 phospho$\mathrm{p} 53$ 과 $\mathrm{GADD} 45$ 단백질 발현 증가가 $\mathrm{RC}$ 와 $\mathrm{AP}$ 추출물 각각을 후 처리한 결과 점차 감소(Fig. $4 \mathrm{~A}, \mathrm{Fig} .4 \mathrm{~B}), \mathrm{DNA}$ 상해 회복에 관련된 $\mathrm{CPD}$ 양의 감소(Fig. $3 \mathrm{~A}, \mathrm{Fig} .3 \mathrm{~B})$, 세포 고사율 감소
(Fig. 2B), 세포 활성도 증가(Fig. 1, Fig. 2A) 되는 것으로 보아 $\mathrm{RC}$ 와 $\mathrm{AP}$ 추출물이 자외선에 의한 세포고사를 보호하는 효능 이 있다고 생각이 된다.

본 연구 결과를 토대로 하여 향후 연구에서는 RC와 $\mathrm{AP}$ 추 출물이 p53 경로와 관련된 다른 유전자들 예를 들면 p21, $\mathrm{MDM} 2$ 등의 발현 양상을 어떻게 변화시키는지를 분석하고자 한다.

\section{감사의 글}

이 논문은 2011학년도 원광대학교의 교비지원에 의해서 수 행됨.

\section{References}

1. Bae, J. Y., Lim, S. S,, Choi, J. S. and Kang, Y. H. 2007. Protective actions of Rubus coreanus ethanol extract on collagenous extracellular matrix in ultraviolet-B irradiation-induced human dermal fibroblasts. Nutr Res Pract 1, 279-284.

2. Baek, E. Y., Lee, S. M., Lee, J. E., Park, E. K., Kim, Y. R., Jung, I. K. and Kim, J. H. 2013. Effect of Rubus coreanus Miquel on prostate tumour growth. J Funct Food 5, 14781486.

3. Brew, C. T., Aronchik, I., Hsu, J. C., Sheen, J. H., Dickson, R. B., Bjeldanes, L. F. and Firestone, G. L. 2006. Indole-3-carbinol activates the ATM signaling pathway independent of DNA damage to stabilize p53 and induce G1 arrest of human mammary epithelial cells. Int J Cancer 118, 857-868.

4. Chang, S. H., Jung, E. J., Park, Y. H., Lim, D. G., Ko, N. 
Y., Choi, W. S., Her, E., Kim, S. H., Choi, K. D., Bae, J. H., Kim, S. H., Kang, C. D., Han, D. J. and Kim, S. C. 2009. Anti-inflammatory effects of Artemisia princeps in antigen-stimulated $\mathrm{T}$ cells and regulatory $\mathrm{T}$ cells. J Pharm Pharmacol 61, 1043-1050.

5. Cho, J. Y., Jeong, J. H., Kim, J. Y., Kim, S. R., Kim, S. J., Lee, H. J., Lee, S. H., Park, K. H. and Moon, J. H. 2013. Change in the content of phenolic compounds and antioxidant activity during manufacturing of black raspberry (Rubus coreanus Miq.) wine. Food Sci Biotechnol 22, 1237-1244.

6. Choi, E. J. and Kim, G. H. 2013. Antioxidant and anticancer activity of Artemisia princeps var. orientalis extract in HepG2 and Hep3B hepatocellular carcinoma cells. Chin J Cancer Res 25, 536-543.

7. Choi, W. H., Kim, D. S., Ann, H. S., Lee, Y. M. and Ahn, R. M. 2005. Combined effect of Korean red ginseng and EGb 761 on ultraviolet B-induced contact hypersensitivity. $J$ Environ Toxicol 20, 143-151.

8. Choung, M. G. and Lim, J. D. 2012. Antioxidant, anticancer and immune activation of anthocyanin fraction from Rubus coreanus Mique fruits (Bokbunja). Korean J Med Crop Sci 20, 259-269.

9. Gambichler, T., Tigges, C., Dith, A., skrtgan, M., Scola, N., Altmeyer, P. and Kreuter, A. 2011. Impact of etanercept treatment on ultraviolet B-induced inflammation, cell cycle regulation and DNA damage. Br J Dermatol 164, 110-115.

10. Gao, M., Li, X., Dong, W., Jin, R., Ma, H., Yang, P., Hu, M., Li, Y., Hao, Y., Yuan, S., Huang, J. and Song, L. 2013. Ribosomal protein $\mathrm{S} 7$ regulates arsenite-induced GADD45a expression by attenuating MDM2-mediated GADD45a ubiquitination and degradation. Nucleic Acids Res 14, 5210-5222.

11. Ha, S. E, Shin, D. H., Kim, H. D., Shim, S. M., Kim, H. S., Kim, B. H., Lee, J. S. and Park, J. K. 2010. Effects of ginsenoside Rg2 on the ultraviolet B-induced DNA damage responses in HaCaT cells. Naunyn Schmiedebergs Arch Pharmacd 382, 89-101.

12. Ha, S. E., Kim, H. D., Kang, J. R. and Park, J. K. 2011. Effects of paprika extract and its components on cell death and expression of p53 and GADD45 genes in ultraviolet B-exposed HaCaT cells. J Life Sci 21, 753-760.

13. Hwang, S. J., Cha, J. Y., Park, S. G., Joe, G. J., Kim, H. M., Moon, H. B., Jeong, S. J., Lee, J. S., Shin, D. H., Ko, S. R. and Park, J. K. 2002. Diol- and triol-type ginseng saponins potentiate the apoptosis of NIH3T3 cells exposed to methyl methanesulfonate. Toxicol Appl Pharmacol 181, 192-202.

14. Lim, J. W., Jeong, J. T. and Shin, C. S. 2012. Component analysis and sensory evaluation of Korean black raspberry (Rubus coreanus Mique) wines. Int J Food Sci Technol 47, 918-926

15. Jeong, S. J., Han, S. H., Kim, D. Y., Lee, J. C., Kim, H. S., Kim, B. H., Lee, J. S., Hwang, E. H. and Park, J. K. 2007. Effects of mRg2, a mixture of ginsenosides containing $60 \%$ $\mathrm{Rg} 2$, on the ultraviolet B-induced DNA repair synthesis and apoptosis in NIH3T3 cells. Int J Toxicol 26, 151-158.

16. Ju, H. K., Cho, E. J., Jang, M. H., Lee, Y. Y., Hong, S. S., Park, J. H. and Kwon, S. W. 2009. Characterization of in- creased phenolic compounds from fermented Bokbunja (Rubus coreanus Miq.) and related antioxidant activity. $J$ Pharm Biomed Anal 49, 820-827.

17. Jung, M. J., Yin, Y., Heo, S. I. and Wang, M. H. 2008. Antioxidant and anticancer activities of extract from Artemisia capillaries. Korean J Pharmacogn 39, 194-198.

18. Kim, H. H., Choi, P. H., Yoo, J. S., Jeon, H., Chae, B. S., Park, J. S., Kim, S. H. and Shin, T. Y. 2012. Ripe fruit of Rubus coreanus inhibits mast cell-mediated allergic inflammation. Int J Mol Med 29, 303-310.

19. Kim, H. D., Ha, S. E., Kang, J. R. and Park, J. K. 2010. Effect of Korean red ginseng extract on cell death responses in peroxynitrite-treated keratinocytes. J Ginseng Res 34, 205211.

20. Kim, J. H., Kim, C. H., Kim, H. S., Kwon, M. C., Song, Y. K., Seong, N. S., Lee, S. E., Yi, J. S., Kwon, O. W. and Lee, H. Y. 2006. Effect of aqueous extracts from Rubus coreanus Mique and Angelica gigas Nakai on anti-tumor and anti-stress activities in mice. Korean J Med Crop Sci 14, 206-211.

21. Kim, M. J., Park, M. H., Jeong, M. K., Yeo, J. D., Cho, W. I., Chang, P. S., Chung, J. H. and Lee, J. H. 2010. Radical scavenging activity and anti-obesity effects in 3T3-L1 preadipocyte differentiation of ssuk (Artemisia princeps Pamp.) extract. Food Sci Biotenhnol 19, 535-540.

22. Kim, Y., Kim, J., Lee, S. M., Lee, H. A., Park, S., Kim, Y. and Kim, J. H. 2012. Chemopreventive effects of Rubus coreanus Miquel on prostate cancer. Biosci Biotechnol Biochem 76, 737-744.

23. Ku, S. C. and Mun, S. P. 2009. Antioxidant activities of ethanol extracts from seeds in fresh Bokbunja (Rubus coreanus Miq.) and wine processing waste. Bioresource Technol 99, 4503-4509.

24. Liang, Y., Lin, S. Y., Brunicardi, F. C., Goss, J. and Li, K. 2008. DNA damage response pathways in tumor suppression and cancer treatment. World J Surg 33, 661-666.

25. Liu, W., Otkur, W., Zhang, Y., Li, Q., Ye, Y., Zang, L., He, H., Hayashi, T., Tashiro, S., Onodera, S. and Ikejima, T. 2013. Silibinin protects murine fibroblast L929 cells from UVB-induced apoptosis through the simultaneous inhibition of ATM-p53 pathway and autophagy. FEBS J 280, 4572-4584.

26. Liu, X., Kim, D. H., Kim, J. M., Park, S. J., Cai, M., Jang, D. S. and Ryu, J. H. 2012. The memory-ameliorating effects of Artemisia princeps var. orientalis against cholinergic dysfunction in mice. Am J Chin Med 40, 993-1005.

27. Ma, B., Zhu, L., Zang, X., Chen, Y., Li, D. and Wang, Y. 2013. Coptis chinensis inflorescence and its main alkaloids protect against ultraviolet-B-induced oxidative damage. $J$ Funct Foods 5, 1665-1672.

28. Marani, G. G., Cambria, A. M., Blandino, G., Muti, P. and Strano, S. 2013. Blockage of melatonin receptors impairs p53-mediated prevention of DNA damage accumulation. Carcinogenesis 34, 1051-1061.

29. Ortolan, T. G. and Menck, C. F. 2013. UVB-induced cell death signaling is associated with G1-S progression and transcription inhibition in primary human fibroblasts. PLOS One 8, e76936. 
30. Piao, M. J., Kang, K. A., Kim, K. C., Chae, S., Kim, G. O., Shin, T., Kim, H. S. and Hyun, J. W. 2013. Diphlorethohydroxycarmalol attenuated cell damage against UVB radiation via enhancing antioxidant effects and absorbing UVB ray in human HaCaT keratinocytes. Enviran Toxicol Pharmacd 36, 680-688.

31. Surjana, D., Halliday, G. M. and Damian, D. L. 2013. Nicotinamide enhances repair of ultraviolet radiation-induced DNA damage in human keratinocytes and ex vivo skin. Carcinogenesis 34, 1144-1149.

32. Visalini, N. S., Smith, D. P., Egger, S., Clements, M. S., Rahman, Md. B. and Armstrong, B. K. 2013. The association of ultraviolet radiation-B (305 nm), season of diagnosis, and latitude on the survival outcome of prostate cancer in the high UV environment of Australia. Cancer Causes Control 24, 2005-2011.

33. Xu, D., Yuan, R., Gu, H., Liu, T., Tu, Y., Yang, Z. and He, L. 2013. The effect of ultraviolet radiation on the transforming growth factor beta $1 /$ Smads pathway and p53 in actinic keratosis and normal skin. Arch Dermatol Res 305, 777-786.

34. Yun, K. W., Jeong, H. J. and Kim, J. H. 2008. The influence of the growth season on the antimicrobial and antioxidative activity in Artemisia princeps var. orientalis. Indust Crops Prod 27, 69-74

\title{
초록 : $\mathrm{HaCaT}$ 세포에서 자외선 $\mathrm{B}$ 에 의해 유도된 DNA 상해반응에 대한 복분자와 쑥 추출물의 효과
}

\author{
이석희 ${ }^{1} \cdot$ 하세은 $^{1} \cdot$ 이준경 ${ }^{2} \cdot$ 박종군 $^{*}$
}

('원광대학교 생명과학부 기초자연과학연구소, ${ }^{2}$ 한풍제약)

본 연구는 복분자와 쑥 추출물이 UVB (자외선-B)에 의한 유전독성의 감소에 효과를 보이는 지를 $\mathrm{HaCaT}$ 세포 를 이용하여 분석하였다. 자외선을 조사하지 않은 정상 세포의 세포활성은 복분자와 쑥 추출물을 처리한 경우 처리하지 않은 대조군과 차이를 나타내지 않았지만, 자외선을 조사한 세포에 복분자와 쑥 추출물을 처리한 경우 처리하지 않은 대조군에 비해 농도 의존적으로 세포 활성을 증가하였다. UVB를 조사한 후 세포의 핵 분절율은 복분자와 쑥 추출물을 처리한 경우 정상 배양액으로 배양한 대조군에 비해 핵 분절율을 각각 약 $20 \%, 15 \%$ 정도 감소하였다. DNA 상해 회복에 반응하는 cyclobutane pyrimidine dimer (CPD)의 잔여량을 확인한 결과, 복분자 와 쑥 추출만 처리한 경우 처리하지 않은 대조군에 비해 차이를 나타내지 않았으나 UVB 조사한 후 복분자와 쑥 추출물을 처리한 경우 정상 배양액으로 배양한 대조군에 비해 농도의존적으로 감소하였다. 세포 상해에 반응하는 유전자인 phospho-p53과 GADD45의 단백질 수준을 Western blot으로 분석한 결과, 자외선을 조사하지 않은 정상 세포에 복분자와 쑥 추출물만 처리한 경우 처리하지 않은 대조군과 비교하여 유의적인 차이를 나타내지 않았지만 $\mathrm{UVB}$ 조사한 후 복분자와 쑥 추출물을 처리한 경우 농도 의존적으로 phospho-p53과 GADD45 단백질 발현량이 감소하였다. 위의 결과에서 복분자와 쑥 추출물은 UVB에 유도된 DNA 상해와 p53 및 GADD45와 같은 상해 반응 단백질의 수준을 감소시키는 것으로 보아 UVB에 의해 손상된 세포의 유전독성을 회복하는 효능이 있다고 생각된다. 